\title{
$D_{2}-1483$
}

UCRL-51817

\section{PROCEDURE FOR PRODUCING A CYLINDER of CELLULOSE ACETATE FOAM CONTAINING ONE GLASS MICROSPHERE}

J. A. Rinde

May 7, 1975

Prepared for U.S. Energy Research \& Deveiopment

Administration under contract No. W-7405-Eng-48

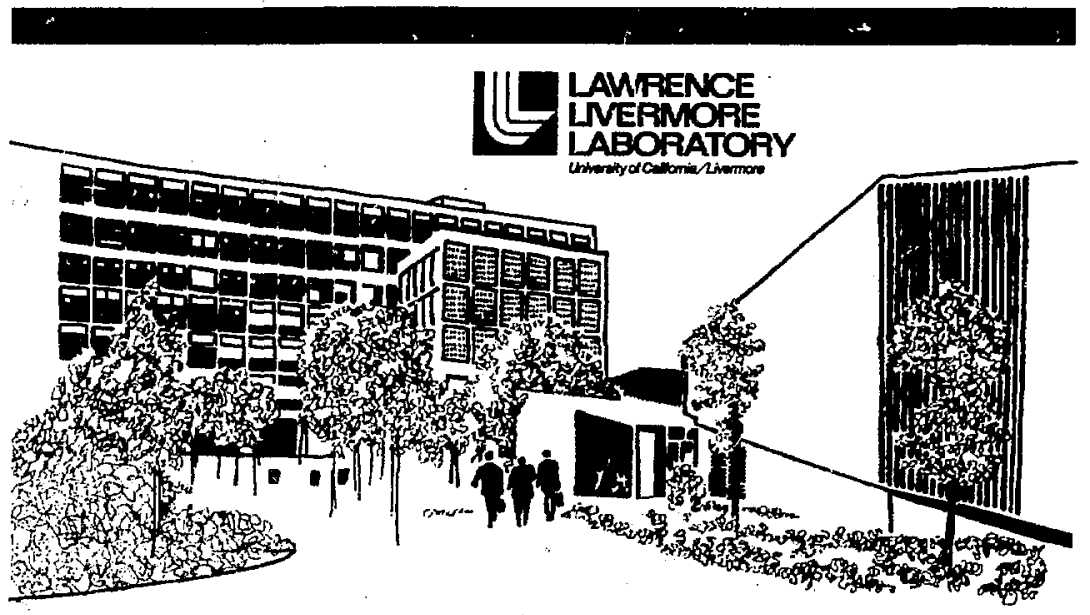


NOTICE

"Thas report was prepsed $\approx$ an eccopat of work upaneored by the Uthed Stelet Governerent. Nsintive the Uniced Status mor ave Uatred Stutes Enerty R warch \& Dewlopment Adalaintratbon, not aly of their employes, nor any of their contractors, mbecontrisetors, or their ompluywer, mukes any warkaty, exprew or boptied, or artumes any beal vabteny of repondbitity for the securicy. cospletears of mefulates of eny inforausion. apperetion prodict or procen ducloted of represents that its of wouks nos intrinfe privatoly-owned rintits."

Printed in the United States of America Available from

National Technical Information Service

U. S. Department of Commerce 5285 Port Royal Road

Springfield, Virginia 22151

Price: Printed Copy $\$$ \#; Microfiche $\$ 2.25$

$\frac{\text { Pages }}{1-50}$
$51-150$
$151-325$
$326-500$
$501-1000$

NTIS

Selling Price

$\$ 4.00$

$\$ 5.45$

$\$ 7.60$

$\$ 10.60$

$\$ 13.60$ 


\section{노}

\section{LAWRENCE INERMORE LAEORATOFY}

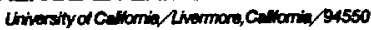

\section{UCRL-51817 \\ PROCEDURE FOR PRODUCING A CYLINDER \\ OF CELLULOSE ACETATE FOAM CONTAINING ONE GLASS MICROSPHERE}

J. A. Rinde

MS, date: May 7, 1975

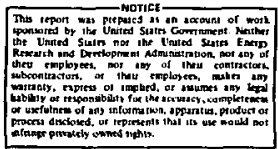




\title{
PROCEDURE FOR PRODUCING A CYLINDER \\ OF CELLULOSE ACETATE FOAM CONTAINING ONE GLASS MICROSPHERE
}

\begin{abstract}
This report, which updates UCRL-51708, ${ }^{1}$ strands containing a single, well-characterdescribes a procedure for producing foam

ized, DT-filled, glass microsphere.
\end{abstract}

\section{Extrusion Process}

APPARATUS

In order to extrude one microsphere in a cylinder of foam and recover it, all steps must be observed with the aid of a low-powar stereomicroscope. Without the use of this instrument, the microsphere will be lost; it may even be lost when the microscope is used.

The required apparatus includes the microscope and a base plate that allows the microscope to be turned horizontally; a clear glass Dewar about $25 \mathrm{~cm}$ long and $8 \mathrm{~cm}$ in diameter; two $\mathrm{X}, \mathrm{Y}, \mathrm{Z}$ micromanipulators, a microvacuum chuck, and a holder for small capillary tubes.

The apparatus is set up as shown in Figs, 1 and 2, In Fig. 1 we show the extrusion apparatus with the glass Dewar, microscope, and $X, Y, Z$ micromanipulator ready for the extrusion. Note that the Dlewar has a clear glass plate fused into the side to allow an undistorted view of the extrusion tip. Figure 2 shows the setup used to add the glass microsphere

1. J. A Rinde and R. R. Stone, Preparation and Fabrication of Low Density Microcellular-Foam Laser Targets, Lawrence Iivermore Laboratory, Rept. JCRL-51708 (1975). to the cellulose acetate solution in the glass capillary tube.

\section{CELLULOSE ACETATE SOLUTIONS}

The following solutions produce good foam by the extrusion process described below.

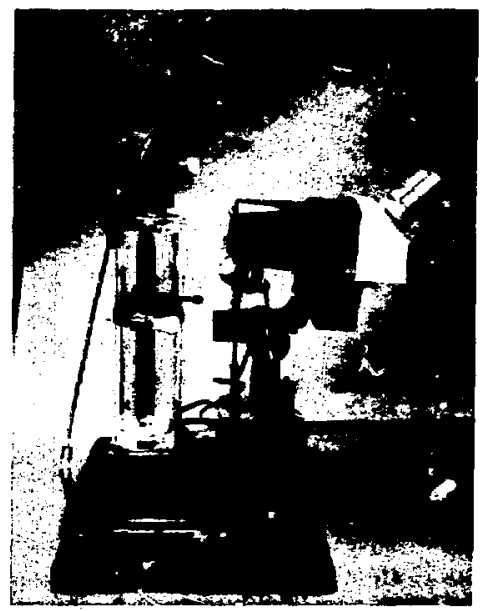

Fig. 1. Extrusion apparatus. 


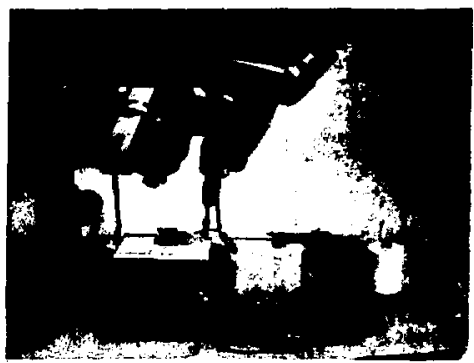

Fig. 2. Microsphere loading apparatus.

\begin{tabular}{lrr} 
& No. I & No. 2 \\
\cline { 2 - 3 } Cellulose acetate, E-4655 & $5 \mathrm{~g}$ & $3 \mathrm{~g}$ \\
$\left.\mathrm{Mg}_{(\mathrm{ClO}}\right)_{2}$, anhydrous & $10 \mathrm{~g}$ & $10 \mathrm{~g}$ \\
Water & $30 \mathrm{~g}$ & $25 \mathrm{~g}$ \\
Ethyl d, I-lactate & $25 \mathrm{~g}$ & $42 \mathrm{~g}$ \\
Acetone & $30 \mathrm{~g}$ & $20 \mathrm{~g}$
\end{tabular}

Solution No, 1 has produced foam of 0.08 to $0.1 \mathrm{~g} / \mathrm{cc}$ density, and solution No. 2 has produced foam with a calculated density of $0.065 \mathrm{~g} / \mathrm{cc}$. Both solutions degrade " ith time, probably due to the formation of a complex between the cellulose acetate and the $\mathrm{Mg}\left(\mathrm{ClO}_{4}\right)_{2}$, and should be made up fresh every two weeks.

\section{PROCEDURE}

The step-by-step procedure for this extrusion is the following:

1. Make extrusion tips from $1,7-\mathrm{mm}$ diameter capillary tube by drawing them down and breaking them off at the desired inside diameter. Tips must be clean and flat on the end for extrusion to take place. In general, it is not advisable to reuse an extrusion tip unless it is cleaned in $\mathrm{HNO}_{3}$. The best length for a tip is about $2.5 \mathrm{~cm}$.

2. Fill the glass Dewar with $0^{\circ} \mathrm{C}$ water, and place in position in front of the microscope. Adjust position of extrusion tip with $\mathrm{X}, \mathrm{Y}, \mathrm{Z}$ micromanipulator and focus microscupe on extrusion capillary.

3. For filling, place the extrusion tif in a holder with the extrusion orifice inside the holder. Add celiulose acetate solution to the capillary tube with a hypodermic syringe to fill it about half full. Set aside the capillary tube containing the acetate solution and

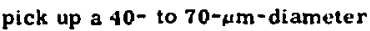
glass :nicrosphere, using the $X, Y, Z$ micromanipulator and the microvacuum chuck. Then place the capillary tube unde $r$ the microscope again and move the microvacuum chuck inside the end of the tube, so that the glass microsphere almost touches the acetate solution (Fig. 2). Turn off the vacuum and use air pressure to blow the glass microsphere off the end of the microvacuum chuck into the acetate solution. Using the syringe again, add more cellulose acetate to the capillary tube to fill 't with solution. At this point, locate the microsphere in the capillary tube and distinguish it from any air bubbles that may be in the solution (see Fig. 3). If the microsphere is located more than $1 \mathrm{~cm}$ from the extrusion orifice then place capillary tube on end so that the microsphere 
will float up closer to the extrusion tip. It $w$ ill be necessary to turn the capillary tube around to allow the microsphere to Hoat away from the wall before it will float tow ard the extrusion orifice. With the microsphere located in proper position and centered in the tube, place the glass capillary tube in the extrusion position and adjust proper rocis and field of view of the microscope. You should be able to sce both the microsphere in the glass capillary tube and the tip of the tube where the solution will be extruded. Lising a rubber bulb, apply pressure to the capillary tube and stirt extrusion. If everything works well, you will see the glass micropphere move down tow ard the tup is the extrusion takes piace; if the procedure does not work satisfactorily, the microspherc will stick to the wall and

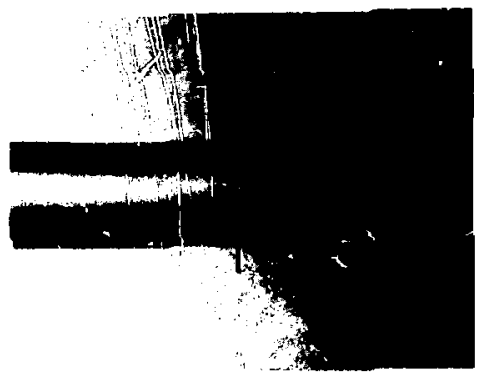

Fig. 3. Glass capillary tube filled with cellulose acetate solution containing a siriole, 50- $\mu \mathrm{m}$-diam, glass microsphere.

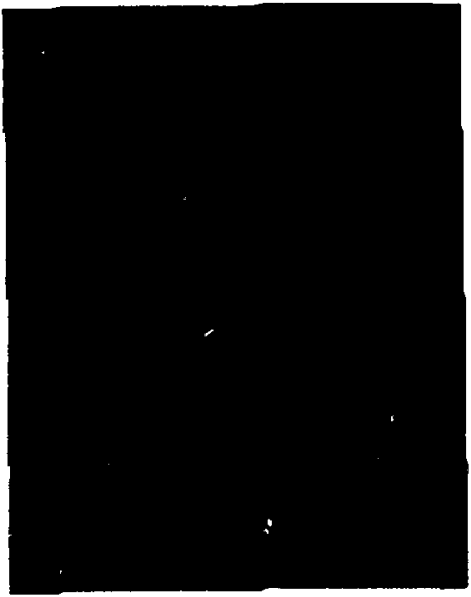

Fif. 4. Cellulose acesate gel strand containing a single, 50- $5 \mathrm{~m}-\mathrm{di}$ ant. glass microsphert. Fixtrusion tip is shown at the very iop of the photograph.

must be thoated ofi before it will extrude. Hfter you sec the microsphere pass through the orifice. reduce the pressure to zero, and allow the foam to soak for $16 \mathrm{~h}$ to reduce the magnesiun ion concontration. rigure $\neq$ shows a cellulose acetat:" gel strand pust below the extrusiun tip.

4. To remove long strands of cellulose acetate gel from a water bath, pick up one end of the strand with a two-prong fork and begin wrapping it over the ends of the fork. l'sing thisi niethod, you can transfer several feet of this soit polymer gei from the water buth to a liquid-pentane bath. This 
procedure gives straight strands

of foam 6-10 cm long after treezt-

drying.

5. To ireeze-dry the polymer gel, transfer the gel to a liquidpentane bath at $-50 \pm 15^{\circ} \mathrm{C}$, 10cated in a shallow Dewar nask. Place this Dewar in a treezedrying apparatus with a liquidnitrogen trap ard start ireezedrying, leaving the frozen strands covered with liquid pentane. After about $4 \mathrm{~h}$ in our apparatus the strands will be completely dry.
6. Using a sharp X-acto knife ${ }^{\circ}$ or razor blade, cut the frozen gel (befor: (reeze-drying ) to length in a bath of cold, liquid pentane. As sn alternative, bond two blades logether sathat they are $100 \mu \mathrm{m}$ apart, and make both cuts at the same time: To obtain flat parallel surfaces, the cutting surfaces must be parallel and beveled on the autside only.

\footnotetext{
Reference to a company or product name does not imply approval or recommendation of the product by the University of California or the U.S. Encrgy Hesearch \& Development Administration to the exclusion of others that may be suitable.
} 